\title{
ANTIBODY RESPONSE OF BEEF CALVES TO EXPERIMENTAL MONOVALENT AND MULTIVALENT INACTIVATED BOVINE VIRAL DIARRHOEA VIRUS VACCINES AS MEASURED BY INDIRECT ELISA METHOD
}

\author{
V. Kurćubić ${ }^{1}$, T. Petrović ${ }^{2}$ R. Đoković ${ }^{1}$, Z. Ilić ${ }^{3}$, M. D. Petrović ${ }^{1}$ \\ ${ }^{1}$ Department of Animal Science, Faculty of Agronomy, Cacak, Cara Dusana 34, 32.000 Cacak, \\ University of Kragujevac, Republic of Serbia \\ ${ }^{2}$ Scientific Veterinary Institute „Novi Sad“, Rumenački put 20, 21000, Novi Sad, Republic of Serbia \\ ${ }^{3}$ Department of Animal Science, Faculty of Agriculture, University of Prishtina - Zubin Potok, Jelene \\ Anzujske bb, Republic of Serbia \\ Corresponding author: vladevet@tfc.kg.ac.rs \\ Original scientific paper
}

Abstract: The objective of this study was to determine the immunogenic properties of two experimental inactivated (mono - and multivalent) vaccines containing BVDV type 1 reference strains (NADL, W1. - 162903, W2. - 172984, W3. - 173481, W4. - 179725) and one local field isolate derived from a calf suffering from mucosal disease (MD). Normal healthy beef calves (Simmental race) of mixed sex, 6 to 7 months of age, were divided into three experimental groups: ten calves vaccinated twice (days 1 and 28) subcutaneously (s/c) with $2 \mathrm{ml}$ of inactivated multivalent vaccine per animal (Group I); ten calves vaccinated twice (days 1 and 28) subcutaneously (s/c) with $2 \mathrm{ml}$ of inactivated monovalent vaccine per animal (Group II) and 9 unvaccinated calves (Control group C). Blood sera were obtained from immunized animals (standard procedure: on days 0, 14, 28, 42 and 56 post-immunization). The immune response to BVDV vaccine strains was assessed by the indirect ELISA method (Bovine Viral Diarrhoea Virus Antibody Test Kit BVDV HerdChek*BVDV Ab, Idexx Scandinavia AB), according to the producer's manual. BVD virus specific antibodies were first detected 42 days after primary immunization and 14 days after secondary immunization in both experimental groups of beef cattle and persisted until day 56 of the experiment. The statistically highly significant differences (of 99\%) between Group I and Group II animals on days 42 and 56 of the experiment suggest considerably higher immunogenicity of the monovalent vaccine used to immunize Group II cattle.

Key words: BVDV, inactivated vaccines, immunogenicity, ELISA 


\section{Introduction}

Bovine viral diarrhoea virus (BVDV) is considered an important cause of economic loss in the cattle industry worldwide (Moenning, 1990). BVDV mainly affects young cattle raised under intensive or semi-intensive systems, causing respiratory, reproductive and digestive disorders (Moenning, 1990; Nettleton \& Entrican, 1995). Vaccination has been the conventional way to control or reduce BVDV-induced losses for the last 50 years (Brock, 2004). The number of licensed vaccines on the market is vast and they are widely used. The use of vaccines may reduce economic losses caused by clinical disease, but does not appear to result in reduction of the prevalence of BVDV infections (O'Rourke, 2002).

Vaccination is still the most common way to control BVD in most European countries (Moennig et al., 2005) and is considered to be a complementary biosecurity tool in countries with high BVDV prevalence, to prevent accidental reinfections of herds in the early stages of control or eradication campaigns. Diagnostic assays play an important role in this context (Houe et al., 2006), particularly for identification of PI animals and, in the later stages, of field infection in vaccinated herds.

Efficacy of commercially available inactivated vaccines is a controversial issue due to the diversity of circulating strains, and the absence of experimental evidence on protection levels during different outcomes of the infection (Bolin, 1990; Bolin, 1995; Corapi, 1990; Chimeno, 2007; Kalaycioglu, 2007; Kelling, 2004; Van Oirschot, 1999).

The disadvantages associated with inactivated BVDV vaccines include: higher price, necessity of revaccination (Brock and Chase, 2000), a longer period required to develop immunity (Bolin, 1995), possible anaphylactic and local reactions at the vaccination site, shorter duration of immunity, and the immune response being directed only against certain antigen variants of the virus (Kelling, 1996; Bolin et al., 1991).

The purpose of this study was to determine the ability of the experimental inactivated vaccines containing BVDV immunogens to induce specific antibodies to type $1 \mathrm{BVDV}$ strains in vaccinated calves. Two different experimental vaccines (monovalent and multivalent) were evaluated using detection of specific antibodies against BVDV, as a measure of their immunogenicity in calves.

\section{Materials and Methods}

All 29 calves in vaccine trials were seronegative before initial vaccination on day 0 , as detected by the ELISA test. The normal healthy beef calves (Simmental race) of mixed sex, 6 to 7 months of age, were divided into three experimental groups. Group I consisted of 10 male calves vaccinated twice (on days 0 and 28) subcutaneously $(\mathrm{s} / \mathrm{c})$ with $2 \mathrm{ml}$ of the inactivated multivalent vaccine per animal. 
Ten calves ( 7 males and 3 females) constituting Group II were inoculated twice (on days 0 and 28) subcutaneously $(\mathrm{s} / \mathrm{c})$ with $2 \mathrm{ml}$ of the inactivated monovalent vaccine per animal. The control group (C) comprised 9 unvaccinated female calves. During the experiment, the calves were kept in a closed building, in free stalls, on slatted floor, under conditions common in intensive calf rearing.

Blood sera for serological testing were collected from the calves of both Group I and Group II using standard procedure at bi-weekly intervals (on days 0, 14, 28, 42 and 56 post vaccination). Blood samples were taken from the control calves on days 0 and 56 of the experiment. After blood sera separation, the samples were frozen at $-20{ }^{\circ} \mathrm{C}$, and examined for the presence of BVDV antibody within fifteen days using ELISA test (Bovine Viral Diarrhoea Virus Antibody Test Kit BVDV HerdChek*BVDV Ab, Idexx Scandinavia AB), according to the producer's manual.

\section{Vaccine preparation}

Monovalent inactivated vaccine. Reference CP strain NADL (CVL Weybridge, provided by courtesy of Dr. Georgina Ibata) was cultured on MDBK (Madin-Darby Bovine Kidney) cell line at a titer of $10^{-6} \mathrm{TCID} / 0.1 \mathrm{ml}$. The MDBK cell line was previously tested and confirmed to be BVDV negative. The suspension of the harvested BVDV was inactivated by the addition of $\beta$ propiolactone. The total inactivation of the BVD harvested virus was controlled in accordance with the Ph EUR 5.0. monograph: Bovine diarrhoea vaccine (inactivated) No 01/2005:1952 (Tests, Inactivation, p. 734). No live virus was detected in the inactivated suspension by culturing on cell line. The suspension was also assayed for sterility using thioglycolate broth, nutrient agar, nutrient broth and Sabouraud broth incubated at $37^{\circ} \mathrm{C}$ and $25^{\circ} \mathrm{C}$ for 14 days. The assay confirmed sterility of the above suspension and the inactivated virus suspension was stored at $-20^{\circ} \mathrm{C}$. Subsequently, during vaccine preparation, merthiolate was added as a preservative to the inactivated virus sample. Sterile $25 \%(\mathrm{AlOH})_{3}$ and a $20 \%$ aqueous solution of saponin (MERCK) were added as adjuvants at a ratio of 1:1.500 to the suspension of the inactivated BVDV vaccine strain. The sterility assay of the prepared vaccine was conducted in the same manner as that of the suspension. The assays confirmed sterility of the vaccine sample.

Multivalent inactivated vaccine. Five $\mathrm{cp}$ BVDV strains were used for the preparation of the polyvalent inactivated vaccine:

1. W1. - 162903, virus titer $10^{6} \mathrm{TCID} / 0.1 \mathrm{ml}, 27 \mathrm{ml}$

2. W2. -172984 , virus titer $10^{5} \mathrm{TCID} / 0.1 \mathrm{ml}, 30 \mathrm{ml}$

3. W3. - 173481 , virus titer $10^{5} \mathrm{TCID} / 0.1 \mathrm{ml}, 30 \mathrm{ml}$

4. W4. - 179725 , virus titer $10^{5} \mathrm{TCID} / 0.1 \mathrm{ml}, 30 \mathrm{ml}$

5. Local BVDV field isolate, virus titer $10^{5} \mathrm{TCID} / 0.1 \mathrm{ml}, 30 \mathrm{ml}$. 
The origin of the first four BVDV strains is CVL Weybridge (provided by courtesy of Dr. Georgina Ibata). They are all BVDV type 1 and the monoclonal antibody typing procedure reveals that they are quite distinct. The fifth strain is local BVDV field isolate, derived from a calf suffering from mucosal disease (MD).

The five CP BVDV strains were cultured at the MDBK cell line. Prior to virus inoculation, the MDBK cell line was checked for the presence of the BVD virus. The test was performed following the procedure Ph EUR 5.0 named: Cell cultures for the production of veterinary vaccines No 01/2005:50204 chapter 5.2.4.; pp. $458 / 459$ (detection of specified viruses), using fluorescein conjugated antibodies (BVD) with the presence of a positive control cell line. The MDBK cell line was negative for the BVDV. The virus suspension was inactivated by the addition of $\beta$ propiolactone. The suspension was assayed for sterility in the same manner as that of the suspension during monovalent vaccine preparation. The assay confirmed sterility of the above suspension. Upon inactivation, $1 \%$ merthiolate was added to the suspension. Inactivated antigens were adsorbed on sterile $\mathrm{Al}(\mathrm{OH})_{3}$, by twofold addition of $25 \%$ sterile adjuvant. The second adjuvant saponin (MERCK, 20\%) was added to the sample. The sterility assay of the prepared vaccine was conducted in the same way as that of the suspension. The assay confirmed sterility of the vaccine sample.

\section{Results and Discussion}

On the first day of the immunization trial (day 0 ), in all 3 experimental groups (Groups I, II and the control-C (III)), the blood serum samples tested serologically negative by the indirect ELISA. One blood serum sample from Group I and 3 sera from the control group were not suitable for the indirect ELISA.

Fourteen and twenty-eight days after primo-vaccination in both experimental groups (Groups I and II), the test calves retained their sero-negative status (Table $1)$.

In Group II, 9 beef calves seroconverted 42 days post primo-vaccination and 1 calf (No. 12) retained its sero-negative status. On the same day of the trial, one calf in Group I seroconverted (No. 6), 5 calves remained sero-negative and 4 calves were classified as suspicious (Nos. 1, 4, 7 and 8) (Table 1).

The result obtained was in agreement with the findings of other authors. Fulton \& Burge (2001) reported that the highest virus-serum neutralizing antibody titer (after a single MLV dose or two doses of inactivated vaccine) was detected on day 42 following primo-vaccination. Also, Brownlie et al. (1995) determined that the humoral immune response to the first dose of inactivated vaccine was weaker, turning into a typical anamnestic response stimulated by the second dose involving a much faster increase in antibody concentrations and higher antibody titers than after the primo-inoculation.

The results on the blood sera of vaccinated cattle in Groups II, I and III (control) for the presence of specific BVD virus antibodies by the ELISA method 
on day 56 of the experiment showed seropositivity in 8 calves of Group II, with the $\mathrm{s} / \mathrm{p}$ value for calf No. 11 (which tested seropositive on day 42) suggesting BVDV suspicious status and calf No. 12 remaining seronegative. All Group I calves remained seronegative excepting calf No. 6 which also tested seropositive on day 42 of the study. Seroconversion did not occur in the control group - the calves tested remained seronegative (Table 1).

Table 1. Results of analysis of the blood sera of vaccinated calves of Groups I, II and III (control) for the presence of specific BVD virus antibodies by the ELISA method on days 0, 14, 28, 42 and 56 of the experiment

\begin{tabular}{|c|c|c|c|c|c|c|c|c|c|c|c|}
\hline \multirow[b]{2}{*}{ Group } & \multirow[b]{2}{*}{ No. } & \multicolumn{2}{|c|}{ Day 0} & \multicolumn{2}{|c|}{ Day 14} & \multicolumn{2}{|c|}{ Day 28} & \multicolumn{2}{|c|}{ Day 42} & \multicolumn{2}{|c|}{ Day 56} \\
\hline & & $\begin{array}{c}\mathrm{s} / \mathrm{p} \\
(450)\end{array}$ & $\begin{array}{c}\mathrm{s} / \mathrm{p} \\
(620)\end{array}$ & $\begin{array}{c}\mathrm{s} / \mathrm{p} \\
(450)\end{array}$ & $\begin{array}{c}\mathrm{s} / \mathrm{p} \\
(620)\end{array}$ & $\begin{array}{c}\mathrm{s} / \mathrm{p} \\
(450)\end{array}$ & $\begin{array}{c}\mathrm{s} / \mathrm{p} \\
(620)\end{array}$ & $\begin{array}{c}\mathrm{s} / \mathrm{p} \\
(450)\end{array}$ & $\begin{array}{c}\mathrm{s} / \mathrm{p} \\
(620)\end{array}$ & $\begin{array}{c}\mathrm{s} / \mathrm{p} \\
(450)\end{array}$ & $\begin{array}{c}\mathrm{s} / \mathrm{p} \\
(620)\end{array}$ \\
\hline \multirow{10}{*}{ I } & 1 & 0.035 & 0.048 & 0.035 & 0.044 & 0.028 & 0.031 & 0.198 & $0.238^{\mathrm{s}}$ & 0.177 & 0.179 \\
\hline & 2 & 0.105 & 0.099 & 0.041 & 0.035 & 0.023 & 0.061 & 0.055 & 0.061 & 0.057 & 0.048 \\
\hline & 3 & 0.055 & 0.027 & 0.055 & 0.052 & 0.064 & 0.086 & 0.174 & 0.162 & 0.109 & 0.103 \\
\hline & 4 & 0.055 & 0.031 & 0.019 & 0.014 & 0.040 & 0.044 & $0.239^{\mathrm{s}}$ & $0.238^{\mathrm{s}}$ & 0.193 & 0.187 \\
\hline & 5 & 0.003 & 0.002 & 0.053 & 0.052 & 0.110 & 0.006 & 0.076 & 0.065 & 0.066 & 0.084 \\
\hline & 6 & 0.019 & 0.018 & 0.016 & 0.014 & 0.028 & 0.027 & $0.427^{\mathrm{p}}$ & $0.440^{p}$ & $0.384^{\mathrm{p}}$ & $0.372^{\mathrm{p}}$ \\
\hline & 7 & 0.044 & 0.040 & 0.020 & 0.014 & 0.037 & 0.027 & $0.250^{\mathrm{s}}$ & $0.280^{\mathrm{S}}$ & 0.095 & 0.084 \\
\hline & 8 & 0.047 & 0.044 & 0.013 & 0.044 & 0.027 & 0.048 & $0.262^{\mathrm{s}}$ & $0.251^{\mathrm{s}}$ & 0.142 & 0.162 \\
\hline & 9 & 0.027 & 0.048 & 0.072 & 0.200 & 0.005 & 0.002 & 0.048 & 0.031 & 0.059 & 0.086 \\
\hline & 10 & & & 0.051 & 0.073 & 0.017 & 0.061 & 0.122 & 0.111 & 0.071 & 0.082 \\
\hline \multirow{10}{*}{ II } & 11 & 0.043 & 0.035 & 0.071 & 0.073 & 0.051 & 0.048 & $0.382^{\mathrm{p}}$ & $0.398^{\mathrm{p}}$ & $0.219^{\mathrm{S}}$ & $0.216^{\mathrm{s}}$ \\
\hline & 12 & 0.040 & 0.035 & 0.073 & 0.069 & 0.071 & 0.111 & 0.130 & 0.050 & 0.134 & 0.134 \\
\hline & 13 & 0.056 & 0.031 & 0.011 & 0.010 & 0.030 & 0.069 & $1.220^{\mathrm{p}}$ & $1.162^{\mathrm{p}}$ & $1.171^{\mathrm{p}}$ & $1.171^{\mathrm{p}}$ \\
\hline & 14 & 0.016 & 0.006 & 0.039 & 0.035 & 0.031 & 0.056 & $1.037^{\mathrm{p}}$ & $0.997^{\mathrm{p}}$ & $0.981^{\mathrm{p}}$ & $0.965^{\mathrm{p}}$ \\
\hline & 15 & 0.037 & 0.031 & 0.049 & 0.048 & 0.059 & 0.015 & $1.051^{\mathrm{p}}$ & $1.006^{\mathrm{p}}$ & $0.934^{\mathrm{p}}$ & $0.924^{p}$ \\
\hline & 16 & 0.049 & 0.052 & 0.077 & 0.111 & 0.099 & 0.094 & $1.110^{\mathrm{p}}$ & $1.116^{\mathrm{p}}$ & $0.879^{p}$ & $0.883^{p}$ \\
\hline & 17 & 0.012 & 0.006 & 0.063 & 0.065 & 0.057 & 0.052 & $1.069^{\mathrm{p}}$ & $1.048^{\mathrm{p}}$ & $1.004^{\mathrm{p}}$ & $0.993^{\mathrm{p}}$ \\
\hline & 18 & 0.064 & 0.090 & 0.065 & 0.065 & 0.059 & 0.048 & $1.554^{\mathrm{p}}$ & $1.512^{\mathrm{p}}$ & $1.504^{\mathrm{p}}$ & $1.468^{p}$ \\
\hline & 19 & 0.051 & 0.061 & 0.029 & 0.014 & 0.024 & 0.010 & $1.457^{\mathrm{p}}$ & $1.394^{\mathrm{p}}$ & $1.384^{\mathrm{p}}$ & $1.367^{p}$ \\
\hline & 20 & 0.073 & 0.073 & 0.037 & 0.048 & 0.020 & 0.052 & $0.792^{\mathrm{p}}$ & $0.727^{\mathrm{p}}$ & $0.859^{p}$ & $0.842^{\mathrm{p}}$ \\
\hline \multirow{9}{*}{$\begin{array}{l}\text { III } \\
\text { (C) }\end{array}$} & 21 & 0.028 & 0.044 & & & & & & & 0.017 & 0.006 \\
\hline & 22 & 0.033 & 0.031 & & & & & & & 0.011 & 0.002 \\
\hline & 23 & 0.057 & 0.065 & & & & & & & 0.021 & 0.038 \\
\hline & 24 & 0.101 & 0.099 & & & & & & & 0.045 & 0.034 \\
\hline & 25 & 0.027 & 0.023 & & & & & & & 0.018 & 0.011 \\
\hline & 26 & 0.021 & 0.040 & & & & & & & 0.011 & 0.002 \\
\hline & 27 & & & & & & & & & 0.011 & 0.002 \\
\hline & 28 & & & & & & & & & 0.014 & 0.006 \\
\hline & 29 & & & & & & & & & 0.035 & 0.025 \\
\hline
\end{tabular}

$\mathrm{s} / \mathrm{p}(450)$ - absorbance values read by ELISA using a $450 \mathrm{\eta m}$ filter $\mathrm{s} / \mathrm{p}(620)$ - absorbance values read by ELISA using a $620 \mathrm{\eta m}$ filter negative $\mathrm{s} / \mathrm{p}$ values - non-marked with superscripts

positive values marked with the 'p' superscript, suspected values marked with the 's' superscript. 
Graham et al. (2003) assessed the presence of antibodies against the structural glycoproteins of the virus in the blood serum using the indirect ELISA method following administration of two inactivated BVDV vaccines (Bovilis and Bovidec) licensed for use in the UK to seronegative calves. The antibody response in both groups of vaccinated calves did not reach its peak value until 5 weeks post revaccination. Given the fact that the final testing for the presence of BVDV antibodies in this experiment was conducted on blood serum samples collected 4 weeks after secondary (booster) vaccination, it is quite likely that some other animals would react positively as well. However, this would not affect the results greatly.

The immune stimulation induced by both experimental (monovalent and multivalent) vaccine formulations administered in this study was, generally, somewhat weaker as compared to the results obtained by other authors. Beer et al. (2000) clearly demonstrated that leukopenia, viremia and nasal shedding after challenge infection of calves with BVDV could be dramatically reduced or were absent after previous parenteral inoculation of an inactivated high dose BVDV vaccine. In contrast, calves vaccinated using a low dose formulation showed only a slight reduction of the described signs of BVDV infection and replication compared with naive controls. The reduction of leukopenia, virus shedding and viremia was strongly dependent on the titer of neutralizing antibodies on the day of challenge infection. It appeared that only animals with a neutralizing antibody titer $>512$ showed a marked protective effect. The induction of such high BVDV specific neutralizing antibody titers was directly dependent of the BVDV antigen amount and could be achieved in vaccinated animals after two applications of the high dosage preparations in a 28 day interval. In contrast to this examination, Bolin et al. (1995) described a neutralization titer of $>256$ as sufficient for the prevention of clinical signs, viremia and virus shedding. Howard et al. (1994) reported that antibody titer values $\left(\log _{10}\right)$ above 3.06 detected by the ELISA test show complete resistance of animals to the infection, whereas those higher than 2.14-3.06 suggest partial resistance. The authors further emphasized that it was not necessary to use live avirulent viruses to achieve protection of the respiratory tract due to the fact that calf resistance was not dependent solely upon local immune response. The antibody titers against BVD virus stimulated by vaccination with inactivated BVD virus were higher than those after natural infection with the same virus. The opinion that modified live vaccines in any case stimulate higher titers of antibodies against BVDV was not confirmed by this study.

The ELISA $s / p$ values reported in this study are relatively low compared to previously reported VN or ELISA titers (Beer et al., 2000; Bolin et al, 1995; Howard et al., 1994). The difference could be the result of the lower BVDV antigen amount in vaccine formulations compared to the previously mentioned experiments. The differences may also be partly explained by the different methods of detection used, ELISA s/p ratio versus ELISA and VN titers, by differences in 
test sensitivity of measurement of an end point titer and by detection of a different population of BVDV-specific antibodies. Raue et al. (2010) reported that indirect ELISA kits coated with whole virus particles showed much better detection rates with sera from animals vaccinated only with inactivated vaccines (PregSure BVD, Bovilis BVD and Bovidec) than the p80 blocking ELISAs. The lower immunogenic potential of the experimental vaccines prepared for this study could also be partly the result of the old-fashioned adjuvants used as opposed to the Quill A, Bay R1005 and Polygen used in other studies.

On the other hand, the objective of this study, however, was not to assess whether the vaccines formulated can provide protection against BVDV infection i.e. clinical signs of the disease and virus shedding. With respect to this, we did not perform challenge infection to estimate the protective efficacy of the experimental vaccines. The main goal of this research was to detect possible differences in the immunogenic potential of multivalent versus monovalent BVDV vaccines under identical experimental conditions at very similar antigen amounts present in the vaccines produced. To this end, the results obtained in this study were statistically analyzed.

All control calves were serologically negative on both day 0 (beginning of the experiment) and day 56 (end of the experiment); therefore, the results obtained were not covered by statistical analysis. A database was created for $\mathrm{s} / \mathrm{p}$ values containing two group variables: days of the control group (days 28, 42 and 56) and days of experimental groups I and II. The database was used to calculate parameters of the descriptive statistical analysis for $\mathrm{s} / \mathrm{p}$ values (the arithmetic mean $-\bar{x}$, standard error of the arithmetic mean $-\mathrm{S}_{\bar{x}}^{\bar{x}}$, standard deviation - SD, coefficient of variation - CV (\%) and variation interval - min-max), the significance of which was tested by analysis of variance and LSD test. The calculated parameters are presented in Tables 2 and 3.

Table 2. Descriptive statistical analysis of s/p values obtained by ELISA test

\begin{tabular}{|c|c|c|c|c|c|c|c|c|}
\hline \multirow{2}{*}{$\begin{array}{l}\text { Days of } \\
\text { the } \\
\text { experiment } \\
\text { (a) }\end{array}$} & \multirow{2}{*}{$\begin{array}{l}\text { Experim. } \\
\text { groups } \\
\text { (b) }\end{array}$} & \multirow[b]{2}{*}{$\mathrm{N}$} & \multirow[b]{2}{*}{$\bar{x}$} & \multirow[b]{2}{*}{$\mathrm{s} \bar{x}$} & \multirow[b]{2}{*}{ SD } & \multirow[b]{2}{*}{ CV (\%) } & \multicolumn{2}{|c|}{ Variations } \\
\hline & & & & & & & Min & Max \\
\hline \multirow{2}{*}{ Day 28} & I & 10 & 0.028 & 0.005 & 0.017 & 60.714 & 0.005 & 0.064 \\
\hline & II & 10 & 0.050 & 0.008 & 0.024 & 48.000 & 0.020 & 0.099 \\
\hline \multirow{2}{*}{ Day 42} & I & 10 & 0.185 & 0.037 & 0.117 & 63.243 & 0.048 & 0.427 \\
\hline & II & 10 & 0.980 & 0.140 & 0.443 & 45.204 & 0.130 & 1.554 \\
\hline \multirow{2}{*}{ Day 56} & $\mathrm{I}$ & 10 & 0.135 & 0.032 & 0.100 & 74.074 & 0.057 & 0.384 \\
\hline & II & 10 & 0.907 & 0.139 & 0.440 & 48.511 & 0.134 & 1.504 \\
\hline \multirow{3}{*}{ Fexp } & $\mathrm{Fa}$ & \multicolumn{7}{|c|}{$25.67130 * *$} \\
\hline & $\mathrm{Fb}$ & \multicolumn{7}{|c|}{$60.94262 * *$} \\
\hline & Fab & \multicolumn{7}{|c|}{$14.00063^{* *}$} \\
\hline
\end{tabular}


The analysis of variance expressed through the $\mathrm{F}$ value suggests statistically significant differences $(* *)$ in the interactions (effects) of values obtained using the ELISA method observed at certain intervals of time - days of the experiment and day-group interaction.

Following the analysis of variance, the LSD test was used to assess the results ( $\mathrm{s} / \mathrm{p}$ values) obtained by the ELISA method. The results are presented in Table 3. The statistically highly significant differences (of 99\%) obtained between Group I and Group II animals on days 42 and 56 after the beginning of the immunization trial clearly demonstrate much higher immunogenic potential of the prepared monovalent experimental vaccine administered to Group II beef calves. The slower development and the weaker immune response in the animals receiving the multivalent vaccine preparation most likely resulted either from the competitiveness developing during the immune response to the larger number of antigens, or from the weaker immunogenicity of the same vaccine.

Table 3. Absorbance values (s/p) obtained by analysis of blood sera of experimental animals using the ELISA method and subjected to LSD test

\begin{tabular}{|c|c|c|c|c|c|c|c|}
\hline GROUPS & $\bar{X}$ & $\mathrm{D}_{2}$ & $\mathrm{~T}_{2}$ & $\mathrm{D}_{1}$ & $\mathrm{~T}_{1}$ & $\mathrm{P}_{2}$ & $\mathrm{P}_{1}$ \\
\hline $\mathrm{P}_{1}$ & 0.028 & $0.952^{* *}$ & $0.879^{* *}$ & 0.157 & 0.107 & 0.022 & $/$ \\
\hline $\mathrm{P}_{2}$ & 0.050 & $0.930^{* *}$ & $0.857^{* *}$ & 0.135 & 0.085 & $/$ & \\
\hline $\mathrm{T}_{1}$ & 0.135 & $0.845^{* *}$ & $0.772^{* *}$ & 0.050 & $/$ & & \\
\hline $\mathrm{D}_{1}$ & 0.185 & $0.795^{* *}$ & $0.772^{* *}$ & $/$ & & & \\
\hline $\mathrm{T}_{2}$ & 0.907 & 0.073 & $/$ & & & & \\
\hline $\mathrm{D}_{2}$ & 0.980 & $/$ & & & & & \\
\hline $\mathrm{P}_{1}=$ day 28, Group I & \multicolumn{7}{|c|}{$\mathrm{T}_{1}=$ day 56, Group I } \\
$\mathrm{P}_{2}=$ day 28, Group II & $\mathrm{T}_{2}=$ day 56, Group II \\
$\mathrm{D}_{1}=$ day 42, Group I & $\mathrm{D}_{2}=$ day 42, Group II
\end{tabular}

\section{Conclusion}

The above results indicate slower development and a weak immune response in animals receiving multivalent vaccine, which most likely resulted either from the competitiveness developing during the immune response to the larger number of antigens or from the weaker immunogenicity of the same vaccine.

The obtained results suggest the necessity to conduct further investigations aimed at increasing the immunogenicity of the vaccines by using higher-quality antigens and adjuvants and defining optimum doses and immunogen inoculation methods for test animals. Also, future studies on the immunogenic and protective values of the vaccines produced must include two subsequent immunization and additional challenge tests using virulent BVDV strains. The need to induce highlevel long-lasting animal protection against BVDV infections is necessary. This 
would enable immunoprophylaxis not only of clinical infections in cattle but also of in utero infections as the greatest concern to BVD/MD epidemiology and pathogenesis.

\title{
Acknowledgment
}

This research was financially supported by the Ministry of Education and Science, Republic of Serbia, TR 31001 project.

\section{Serološki odgovor tovne junadi na eksperimentalnu monovalentnu i multivalentnu inaktivisanu vakcinu pripremljenu od virusa goveđe virusne dijareje, utvrđivan indirektnom ELISA metodom}

\author{
V. Kurćubić, T. Petrović, R. Đoković, Z. Ilić, M.D. Petrović
}

\section{Rezime}

Naše ispitivanje je imalo za cilj ispitivanje imunogenosti dve inaktivisane (mono i multivalentne) vakcine koje sadrže referentne sojeve BVDV tip 1 (NADL, W1. - 162903, W2. - 172984, W3. - 173481, W4. - 179725) i jedan terenski izolat, dobijen iz teleta obolelog od sluzokožne bolesti (MD). Zdrava tovna junad (Simentalske rase), oba pola, stara od 6-7 meseci, bila su podeljena u 3 eksperimentalne grupe. Deset teladi je vakcinisano dvokratno (1. i 28. dana) subkutano (s/c) sa $2 \mathrm{ml}$ inaktivisane multivalentne vakcine po životinji (Grupa I). Deset teladi je vakcinisano dvokratno (1. i 28. dana) subkutano (s/c) sa $2 \mathrm{ml}$ inaktivisane monovalentne vakcine po životinji (Grupa II) i 9 nevakcinisanih teladi (kontrolna grupa C). Od imunizovanih životinja su uzorkovani krvni serumi (standardna procedura: $0,14,28,42$ i 56 dana nakon imunizacije). Imunološki odgovor na vakcinalne sojeve BVDV utvrđen je indirektnom ELISA metodom (Bovine Viral Diarrhoea Virus Antibody Test Kit BVDV HerdChek*BVDV Ab, Idexx Scandinavia $A B$ ), u skladu sa uputstvom proizvođača. Prva pojava specifičnih antitela protiv virusa BVD je utvrđena 42 dana od primarne, odnosno 14 dana od sekundarne imunizacije kod tovne junadi obe eksperimentalne grupe, koja su se zadržala i 56 dana ispitivanja. Utvrđene statistički vrlo značajne razlike (od 99\%) između životinja I i II grupe i 42 i 56 dana od početka ogleda imunizacije ukazuju na znatno snažniju imunogenost monovalentne vakcine, kojom su vakcinisana tovna junad iz ogledne grupe II. 


\section{References}

BEER M., HEHNEN H.R., WOLFMEYER A., POLL G., KAADEN O.R., WOLF G. (2000): A new inactivated BVDV genotype I and II vaccine - An immunization and challenge study with BVDV genotype I. Veterinary Microbiology 77, 195-208. BOLIN S.R. (1990): Control of bovine viral diarrhoea virus. Rev Sci Tech, 9, 163 171.

BOLIN S.R., LITTLEDIKE E.T., RIDPATH J.F. (1991): Serologic detection and practical consequences of antigenic diversity among bovine viral diarrhea viruses in a vaccinated herd. Am J Vet Res, 52, 1033-37.

BOLIN S.R. (1995): Control of bovine viral diarrhea infections by use of vaccination. Vet Clin N Am-Food, A 11, 3, 615-25.

BOLIN S.R., RIDPATH J.F. (1995): Assessment of protection from systemic infection or disease afforded by low to intermediate titers of passively acquired neutralizing antibody against bovine viral diarrhea virus in calves. Am. J. Vet. Res., 56, 755-759.

BROCK K.V. (2004): Strategies for the control and prevention of bovine viral diarrhea virus. Vet Clin North Am Food Anim Pract, 20, 171-180.

BROCK K.V., CHASE C.C.L. (2000): Development of a fetal challenge method for the evaluation of bovine viral diarrhea virus vaccines. Vet Microbiol, 77, 1-2, 209-214.

BROWNLIE J., CLARKE M.C., HOOPER L.B., BELL G.D. (1995): Protection of the bovine fetus from bovine viral diarrhoea virus by means of a new inactivated vaccine. Vet Rec, 137, 3, 58-62.

CHIMENO ZOTH S., LEUNDA M.R., ODEÓN A., TABOGA O. (2007): Recombinant E2 glycoprotein of bovine viral diarrhea virus induces a solid humoral neutralizing immune response but fails to confer total protection in cattle. Braz J Med Biol Res, 40, 813-818.

CORAPI W.V., DONIS R.O., DUBOVI E.J. (1990): Characterization of a panel of monoclonal antibodies and their use in the study of the antigenic diversity of bovine viral diarrhea virus. Am J Vet Res, 51, 1388-1394.

FULTON R.W. AND LURINDA J. BURGE (2001): Bovine viral diarrhea virus types 1 and 2 antibody response in calves receiving modified live virus or inactivated vaccines. Vaccine, 19, 264-274.

GRAHAM D. A., GERMAN A., MAWHINNEY K. AND GOODALL E. A. (2003): Antibody responses of naive cattle to two inactivated bovine viral diarrhoea virus vaccines, measured by indirect and blocking ELISAs and virus neutralisation. Vet Rec, 152,,795-800.

HOUE H., LINDBERG A., MOENNIG V. (2006): Test strategies in bovine viral diarrhea virus control and eradication campaigns in Europe. Journal of Veterinary Diagnostic Investigation, 18, 427-436. 
HOWARD C.J., CLARKE M.C., SOPP P., BROWNLIE J. (1994): Systemic vaccination with inactivated bovine virus diarrhoea virus protects against respiratory challenge. Vet Microbiol, 42, 171-179.

KALAYCIOGLU A.T. (2007): Bovine viral diarrhoea virus (BVDV) diversity and vaccination. A review. Vet Q, 29, 60-67.

KELLING C.L. (2004): Evolution of bovine viral diarrhea virus vaccines. Vet Clin North Am Food Anim Pract, 20, 115-129.

KELLING C.L. (1996): Planning bovine viral diarrhea virus vaccination programs. Vet Med-Us, 9, 873-77.

MOENNIG V., HOUE H., LINDBERG A. (2005): BVD control in Europe: current status and perspectives. Animal Health Research Reviews, 6, 63-74.

MOENNING V. (1990): Pestiviruses: a review. Vet Microbiol, 23, 35-54.

NETTLETON PF, ENTRICAN G. (1995): Ruminant pestiviruses. Br Vet J, 151, 615-42.

O'ROURKE K. (2002): BVDV: 40 years of effort and the disease still has a firm hold. J Am Vet Med Ass, 220, 12, 1770-1773.

VAN OIRSCHOT J.T., BRUSCHKE C.J., VAN RIJN P. (1999): Vaccination of cattle against bovine viral diarrhoea. Vet Microbiol, 64, 169-83.

RAUE R., SILKE S. HARMEYER, NANJIANI I.A. (2010): Antibody responses to inactivated vaccines and natural infection in cattle using bovine viral diarrhoea virus ELISA kits: Assessment of potential to differentiate infected and vaccinated animals. The Veterinary Journal, article in press. doi:10.1016/j.tvj1.2009.12.013. 